\title{
SPEECH ACT AND POLITENESS TRATEGY USED BY PRE-SERVICE TEACHER IN ONLINE LEARNING IN SMA LAB UNDISKSHA
}

\author{
I Gede Rizky Aditiya', I Nyoman Adi Jaya², Dewa Putu Ramendra ${ }^{3}$ \\ 1,2,3) Universitas Pendidikan Ganesha \\ igederizkyaditiya@gmail.com ${ }^{1}$
}

\begin{abstract}
Language is an essential tool that we use in our daily life. In general, language is used as a tool to convey information. In using language, speakers must pay attention to the language used. Language users should do this to avoid or minimize errors in conveying information to listeners. This study aims to determine what types of speech acts and politeness strategies are used by pre-service teachers when teaching online classes. This research is expected to provide an overview of how speech acts and politeness strategies can affect educational activities. This research is a qualitative descriptive study. This research was conducted using two steps. The researcher's first step is to observe how preservice teachers use speech act and politeness strategies in online classes. Then the researcher will conduct interviews with research subjects or pre-service teachers to verify the data that has been observed. In conducting this research, the researcher used two theories as to the research foundation. The first theory is Searle's theory of speech act types and Brown and Levinson's theory of politeness strategies. The study found that if pre-service teachers use five types of speech acts, they are representative, directive, commissive, expressive, and directive. This study also found that pre-service teachers used more directive speech acts in teaching online classes than other types of speech acts. In addition to the use of speech acts, this study also found that pre-service teachers also use four politeness strategies in teaching online classes. The four types of politeness strategies are bald-onrecord, positive politeness, negative politeness, and off-record.
\end{abstract}

Keyword: Online Learning, Politeness Strategy, Speech Act

\section{Introduction}

A language is a tool that we use to communicate in everyday life. Using language, we can convey our thoughts (Grundlingh, 2017, as cited in Amirstany and Zamzani, 2019). In addition to conveying the thoughts we have, we can also convey the actions we will take by using language. The use of language to show the action taken is called a speech act. The speech act is one part of pragmatics that studies how humans use language to convey or show actions. In the science of speech act, when someone says something using language, that person will also do something (Austin, 1962).

According to Searle (1969), the speech act itself is divided into five types: representative, directive, commissive, expressive, and declarative. Each type of speech act has its characteristics when used. Representative speech act has a characteristic wherein the use of this type of speech act the speakers will convey what they believe to the listener. What was conveyed was based on facts or direct experience of the speaker (Yule, 1966). The characteristic of a directive speech act is the use of command to make someone do something or order someone else. The commissive type of speech act has the characteristic of using language to convey plans or activities that will be carried out in the future. The expressive speech act has a characteristic where the speaker will use language to convey their feelings. In 
comparison, the declarative speech act has a characteristic where language is used to change conditions or situations around language speakers.

In using a language, we must also pay attention to various aspects to reduce the occurrence of misunderstandings that can occur. One aspect that must be considered is the politeness strategy. Politeness strategy is a strategy used to make the communication process run well and prevent misunderstandings (Leech, 1983) cited by (Fitriyani and Andriyanti, 2020). If we ignore the use of politeness strategies in communication, not only misunderstandings can occur, but we can also make listeners feel depressed to the point of making listeners uncomfortable. Because of this, we must pay attention to the use of politeness strategy in the communication process that we do.

According to Brown and Levinson (1987), speech acts are divided into four types, bald-on-record, positive politeness, negative politeness, and off-record. Baldon-record is a type of politeness strategy that is more concerned with efficiency in the communication process. Because of this, bald-on-record ignores the use of effort to reduce misunderstandings and inconveniences in the communication process. Positive politeness is a type of politeness strategy that emphasizes comfort in communicating. This sense of comfort is formed to make the communication process run well. A negative politeness strategy is a type of politeness strategy that focuses on using strategies to prevent misunderstandings in the communication process. Off-record is a type of speech act that can be a bit like a negative politeness strategy. However, this strategy is different from negative politeness. In conveying information, the off-record politeness strategy conveys information indirectly. Off-record politeness depends on how the listener interprets the words conveyed by the speaker.

In everyday life, we can see how speech act and politeness strategy are carried out in communication activities. We can see examples of this application in learning activities. Speech act and politeness strategy used in learning activities are generally used more by teachers. These two essential aspects of language can support success in learning activities. The importance of those two appears because the language used in learning activities can affect the success of learning activities (Huth, 2011, as cited in Amirstany and Zamzani, 2019). Therefore, teachers must be able to maximize the use of these two aspects in learning activities in order to maximize learning activities.

In 2020 the learning model changed from face-to-face learning to online learning. This change occurred due to the pandemic that occurred due to the Covid-19 virus (Haleem, Javaid, \& Vaishya, 2020). This change provides new challenges for teachers in providing quality learning for students. Teachers must be able to use the correct language when providing online learning. Teachers must be able to minimize misunderstandings in learning activities so that students can understand the material well. Based on this problem, the researcher is interested in researching what type of speech acts and politeness strategies the pre-service teacher uses in online learning activities. The researcher also wants to find out what types of 
speech acts are most often used by preservice teachers when teaching in online classes. In this study, the researcher chose a pre-service that was conducting practice teaching programs. The researcher chose the pre-service teacher as the subject of this study because the researcher wanted to see how the pre-service teacher used speech act and politeness strategy to carry out learning activities.

In conducting this research, the researcher used previous research that examined the same topic as a reference for conducting research. The previous research used as a reference for this research is the research conducted by Merdana, Seken, and Adi Jaya Putra (2013). This study examines speech acts produced by teachers and students in elementary school. In this study, they found that teachers produced more speech acts than students. Another research used as a reference in this research is the research conducted by Karlinda Orin and Yuliasri Issi in 2016. This research examines how representative speech is used in English debate competitions. This study found that in the English debate competitions, twelve types of representative speech were used (Orin and Issi, 2016). In addition to these two studies, this study also uses research conducted by Santi Fitriyani and Erna Andriyanti in 2020. In this study, they examine how the politeness strategy is used in interactions in EFL classes. This study found that there were three types of politeness strategies used in the interactions that occurred in the EFL class: positive politeness, negative politeness, and bald-on record (Fitriyani and Andriyanti, 2020).

\section{Research Method}

This study uses a descriptive qualitative research model. In this study, the researcher described the study results by describing the data obtained and not using numbers (Anggito and Setiawan, 2018). In order to obtain the desired data, this research uses two methods. The first is non-participant observation. Nonparticipant observation is an observation that is carried out indirectly or indirectly involved with the object of observation (Anggito and Setiawan, 2018). The second method used is a semi-structured interview. Semi-structured interviews are interviews conducted by developing questions but still adjusting to previously made questions (Stukey, 2013). This study also uses three types of instruments to assist in data collection. The instrument used is a video containing learning activities carried out by the research subject, an interview guide to verify the data. Finally, this research uses an observation checklist containing the data that has been obtained. In analyzing the data that has been obtained, this study uses data analysis techniques proposed by Miles and Huberman. Data analysis was carried out in three stages, data reduction, data display and conclusion drawing/verification (Miles and Huberman, 1994). This study also uses the triangulation method in analyzing the data. This study uses two types of triangulation, namely investigator triangulation and triangulation theory. Triangulation investigators carried out in this study were in collaboration with people who were experts in the field being studied, namely speech act and politeness strategy. While the triangulation theory carried out in this study was to adjust the 
data with the speech act theory and politeness strategy.

\section{Findings and Discussion}

This study uses the theory of the type of speech act from Searle (1969) to classify the type of speech act used by preservice teachers. This study found that when teaching in online classes, the preservice teacher use five types of speech acts: representative, directive, commissive, expressive, and declarative. This study also found that pre-service teachers used four types of politeness strategies when teaching. They are bald-on-record, positive politeness, negative politeness, and off-record. The following is the data that has been obtained, along with an explanation.

\subsection{The Type of Speech act used by Pre- service Teacher \\ 3.1.1 Representative}

According to Searle (1969), a representative speech act is a type of speech act used when we want to convey something that we already think is true. The assumption that something is true is based on facts or experiences already known to the speaker (Yule, 1966). In this study, researchers found that pre-service teachers used representative speech acts in 18 utterances (7\% of the data) when teaching online classes. The types of representative speech acts found are affirming, concluding, and informing. The following is an example of the use of representative speech acts:

"Meet is the resource for protein"

This sentence is spoken by the preservice teacher when they want to provide information to students. This sentence is included as representative because this sentence indicates that the pre-service teacher already knows that meat is a source of protein. The pre-service teacher shows what he already knows in this sentence by explaining how protein can be obtained from meat.

\subsubsection{Directive}

The directive speech act is used when someone wants to get someone else to do something for us (Searle, 1969). Based on the data obtained, the preservice teacher used this type of speech act in 153 utterances (60\% of the data). The types of directive speech act that were found were commanding, requesting, inviting, and questioning. The following is an example of the use of a directive speech act by a pre-service teacher:

"Please tell your name first then your answer."

This sentence is spoken by the preservice teacher when he gives instructions to students when students will give answers to the questions given. This sentence is categorized as a directive speech act because there is the imperative verb "tell" in this sentence. Pr-service teachers use these verbs to give direct instructions to students to do something.

\subsubsection{Commissive}

When we want to express plans or actions that will be carried out in the future, it can be categorized as a commissive speech act (Searle, 1969). Based on the data that has been obtained, this study found that pre-service teachers used commissive speech acts in 28 utterances (11\% of the data). The types of commissive speech acts found are a promise, threat, and planning. The following is an example of the use of a 
commissive speech act by a pre-service teacher:

"Next we will have bread"

This sentence is produced by the pre-service teacher when he wants to tell if the next plan is to discuss bread. This sentence categorizes as the type of commissive speech act because there is the use of the word "will" in this sentence". This word indicates an action that the preservice teacher will take in the future where he will continue to discuss the material.

\subsubsection{Expressive}

The expressive speech act is a speech act used to show our feelings, such as feeling happy, sad, hateful, thanking, and congratulating (Searle, 1969). This study found that the pre-service teacher used an expressive speech act in 39 utterances (15\% of the data). The type of directive speech act that was found was congratulating and thanking. The following is an example of the use of expressive speech acts by pre-service teachers:

"Thanks Adi for sharing your favorite fruit and vegatable"

This sentence is produced by a pre-service teacher giving thanks to one of the students who has been willing to answer the questions given. In this sentence, there is the use of the word "Thanks". Here, the word "Thanks" is used by the pre-service teacher to show his gratitude to students who have dared to answer the questions he gave.

\subsubsection{Declarative}

The declarative speech act is the use of language to change the circumstances around the speaker (Searle,
1969). From the data that has been obtained, this study found that pre-service teachers used declarative speech acts in 19 utterances ( $7 \%$ of the data). The following is an example of the use of a declarative speech act by a pre-service teacher:

"So our material today is Heat and Temperature"

This sentence is used by preservice teachers who want to tell students if the material to be studied that day is heat and temperature. This sentence is categorized as a declarative speech act because this sentence causes a change in conditions where students do not know the learning material to become aware of the material to be studied. In addition, there is the use of the phrase "our material today". The use of that phrase help to clarify if the pre-service teacher wants to tell students if the material being studied is heat and temperature.

\subsection{The type of speech act most often used by pre-service teachers}

In this study, the researchers found that pre-service teachers used more directive speech acts in teaching online classes at SMA LAB Undiksha. This study found that pre-service teachers used directive speech acts in 153 utterances ( $60 \%$ of the data). Based on the interviews with pre-service teachers, this study found that the reasons behind the use of directive speech acts are more dominant than other speech acts. The reason is a learning model that uses online learning methods. The application of learning models like this is not easy. Online learning must face several obstacles, such as signal interference, that can affect the success of learning activities. In order to maximize success, there needs to be an 
effort to maximize success in learning activities. Because of this, the pre-service teacher uses more directive speech acts or gives more instructions to students so students can well understand the information about the material.

\subsection{Politeness Strategy Used by The Pre- service Teacher}

\subsubsection{Bald-on-record}

Bald-on-record is a type of politeness strategy that emphasizes efficiency in the communication process. Because efficiency is essential, this type of politeness in its application to convey information does not pay attention to strategies or efforts to prevent misunderstandings or offences between speakers and listeners (Brown and Levinson, 1987). After conducting this research, the researcher found that preservice teachers use bald-on-record in providing learning to students in online classes. The following is an example of using bald-on-record by a pre-service teacher:

"I want you to read the example first"

This sentence is used by the preservice teacher when he gives instructions to students to read one of the materials being studied. This sentence is categorized as a sentence that uses bald-on-record because the pre-service teacher says this sentence without regard to strategies or efforts to overcome misunderstandings or offences that may occur. Pre-service conveys information directly to students where it asks students to read the material. In this sentence, the pre-service teacher ignores whether this sentence can make students offended or even feel uncomfortable.

\subsubsection{Positive politeness}

The positive politeness strategy is a strategy used to make the communication process feel comfortable (Brown and Levinson, 1987). This type of politeness strategy must pay attention to fifteen stages to make communication between speakers and listeners feel comfortable in its application. One of the stages is that the speaker must give an optimistic nature to the listener. In this study, researchers found that pre-service teachers used this type of politeness strategy to make students feel comfortable participating in learning. The following is an example of the use of this type of politeness strategy by pre-service teachers:

"We are doing it so you can improve your vocabulary"

The sentence is categorized as a positive politeness strategy because the pre-service teacher provides a sense of comfort to students in the sentence. That was done by showing a sense of optimism by telling If students follow learning activities well, they can benefit because they can improve their mastery of words or vocabulary by participating in learning activities.

\subsubsection{Negative politeness}

Negative politeness is a type of politeness strategy that uses prevention strategies to overcome misunderstandings or offences that can occur (Brown and Levinson, 1987). In its application, this type of politeness must pay attention to ten ways. One of those ways is conveying pessimism. The following is an example of the application of a negative politeness strategy by a pre-service teacher:

"Angelo, can you read the second paragraph?" 
This sentence is used by the preservice teacher when he wants to give instructions to students to read one of the materials being studied. The real purpose of using this sentence is to question the students' ability to read the material. Based on this, the pre-service teacher showed a sense of pessimism in giving instructions to students. By showing this feeling, the teacher does not force students to read the material. Students are given the freedom to refuse or accept the instructions given. The pre-service teacher does this action to prevent any offence that students can feel.

\subsubsection{Off-record}

Off-record is a type of politeness strategy that discloses information indirectly to prevent misunderstanding or offence (Brown and Levinson, 1987). In applying this type of politeness strategy, Brown and Levinson say that we must use fifteen steps. In this study, researchers found that pre-service uses one of the fifteen steps in implementing this type of politeness strategy. The pre-service teacher uses a step where he uses an ellipsis or provides incomplete information. The following is an example of the use of an off-record type politeness strategy by a pre-service teacher:

"The higher the temperature of an object, so the temperature of the object will be...?"

This sentence is used by the preservice teacher when he wants to give questions to students about the material being studied. This sentence is included in the category that uses the off-record type of politeness strategy because this sentence conveys an incomplete sentence. The use of the off-record politeness strategy can be seen from the use of questions that are ellipsis in the sentence. Pre-service teachers use this question model to make students feel unburdened or objected to answering the questions given.

\section{Conclusion}

Based on the data described above, it can be concluded that when teaching in online classes at SMA LAB Undiksha, the pre-service teacher who is conducting a practice teaching program uses five types of speech acts. Pre-service teachers' types of speech acts are representative, directive, commissive, expressive, and declarative. In using speech acts, pre-service teachers use more directive speech acts when teaching in online classes. This study found that the pre-service teacher found that the directive speech act was used in 153 utterances ( $60 \%$ of the data). The results of this study also found that pre-service uses four types of politeness strategies when teaching. The types of politeness strategies used are bald-on-record, positive politeness, negative politeness, and offrecord. From the results of this study, the researcher hopes that it can provide benefits to readers and other researchers who want or will research about the same object as this research. The researcher hopes that this research can be used as a reference or reading material to provide information about how speech acts are used in online learning. 


\section{References:}

Anggito, A and Setiawan, J. (2018). Metodologi penelitian kualitatif. Sukabumi, Jawa Barat: CV Jejak.

Austin, J. L. (1962). How To Do Things With Words. New York: Oxford University Press.

Brown, P., \& Levinson, S. (1987). Politeness: Some universals in language usage. Cambridge: Cambridge University Press

Fitriyani, S and Andriyanti, E. (2020). Teacher and Students' Politeness Strategies in EFL. Indonesian Journal of English Language Teaching and Applied Linguistics, 4, 256-273. Retrieved from https://www.researchgate.net/pu blication $/ 342158380$ Teacher and Students' Politeness Strategies in EFL Classroom Interactions

Fitriyani \& Andriyanti (2020). Teacher and Students' Politeness Strategies in EFL Classroom Interactions. Indonesian Journal of English Language Teaching and Applied Linguistics, 4(2), 259-273. Retrieved from https://www.researchgate.net/pu blication/342158380 Teacher and Students' Politeness Strategies in EFL Classroom Interactions

Haleem, Javaid, \& Vaishya. (2020). Effects of COVID-19 pandemic in daily life, Current Medicine Research and Practice. Retrieved from

https://doi.org/10.1016/j.cmrp.202 $\underline{0.03 .011}$

Merdana, Seken, \& Adi Jaya Putra. (2013). AN ANALYSIS OF SPEECH ACTS PRODUCED BY ELEMENTARY SCHOOL TEACHERS AND STUDENTS TO FACILITATE TEACHING AND LEARNING AT SDN 10
PRINGGASELA EAST LOMBOK.

e-Journal Program Pascasarjana Universitas Pendidikan Ganesha, 1. Retrieved from https://media.neliti.com/media/p ublications/118108-EN-ananalysis-of-speech-actsproduced-by-e.pdf

Searle, J. R. (1969). Speech acts. New York: Syndics of the Cambridge University Press.

Stuckey, H. L. (2013). Three types of interviews: Qualitative research methods in social health. Journal of Social Health and Diabetes, 1(2). Retrieved from https://www.thiemeconnect.de/products/ejournals/ht $\underline{\mathrm{ml} / 10.4103 / 2321-}$ 0656.115294\#BR 4

Yule, G. (1966). Pragmatics. New York: Oxford Press.

Yuliasri. I. (2016). REPRESENTATIVE SPEECH ACTS PERFORMED BY THE DEBATERS IN AN ENGLISH DEBATE COMPETITION. English Education Journal, 79-86. Retrieved from

https://journal.unnes.ac.id/sju/ind ex.php/eej/article/view/13059/714 $\underline{7}$

Zamzani and Amirstany. (2019). THE FUNCTIONS OF ILLOCUTIONARY SPEECH ACTS USED BY TEACHERS IN THE CLASSROOM INTERACTIONS. LiNGUA, 14(1). Retrieved from https://www.researchgate.net/pu blication/334231073 THE FUNC TIONS OF ILLOCUTIONARY $S$ PEECH ACTS USED BY TEAC HERS IN THE CLASSROOM I NTERACTIONS 